\title{
Effect of Feeding Different Levels of Corn Gluten Feed on Milk Production and Economic Efficiency in Friesian Dairy Cows Rations. Maklad Eman, H. M. ${ }^{1}$; M. Y. El-Ayek ${ }^{1}$; A. M. Abd El-Khabir ${ }^{2}$ and K. M. I. Sharaf ${ }^{2}$ ${ }^{1}$ Animal Production Department, Faculty of Agriculture, Mansoura University, Egypt. \\ ${ }^{2}$ Animal Production Research Institute, Agriculture Research Center, Ministry of Agriculture, Dokki, Giza, Egypt.
}

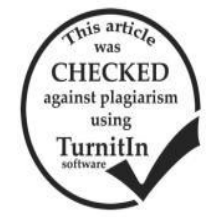

ABSTRACT

In this study, the weight of the twelve cows was ranging from $435-570 \mathrm{~kg}$. The animals in this study were in the $2^{\text {nd }}$ to $4^{\text {th }}$ lactation season. In order to study the production of milk and its composition by the effect of the tested rations, cows were subdivided into four groups (three cows in each group). According to NRC (2001) recommendations all groups were fed individually. The period of the experiment was 140 days ( 20 weeks) after 6 weeks from calving. The four experimental rations as DM were formulated nearly as follows : control: $52 \%$ concentrate feed mixture (CFM) (40\% corn grain, 30\% wheat bran, $23 \%$ undecorticated cottonseed meal, $5 \%$ molasses, $0.5 \%$ salt and $1.5 \%$ limestone) $+20 \%$ corn silage (CS) $+28 \%$ rice straw (RS), experimental ration 1 (Exp.1): 52\% CFM (35\% corn grain, $30 \%$ wheat bran, $10 \%$ corn gluten feed (CG), $18 \%$ undecorticated cottonseed meal, $5 \%$ molasses, $0.5 \%$ salt and $1.5 \%$ limestone) $+20 \%$ CS + 28\% RS, (Exp.2): $52 \%$ CFM ( 32.5\% corn grain, 30\% wheat bran, $15 \%$ CG, $15.5 \%$ undecorticated cottonseed meal, $5 \%$ molass, $0.5 \%$ salt and $1.5 \%$ limestone) $+20 \%$ CS $+28 \%$ RS and (Exp.3): $52 \%$ CFM (30\% corn grain, $30 \%$ wheat bran, $20 \%$ CG, $13 \%$ undecorticated cottonseed meal, $5 \%$ molasses, $0.5 \%$ salt and $1.5 \%$ limestone) $+20 \% \mathrm{CS}+28 \%$ RS. The dry matter intakes (\% body weight) were higher with feeding on Exp.1 or Exp.2 (3.38 and 3.51) respectively, than feeding on control or Exp.3 (3.25 and 3.26, respectively). There was no significant effect on the average daily milk yield with feeding the experimental rations from Week 1 to Week 20. The average daily milk yield results were 13.68, 14.71, 15.73 and $14.79 \mathrm{Kg}$ /day with feeding on the control, Exp.1, Exp.2 and Exp.3, respectively. The highest value was with feeding on Exp.2 than the other rations. Regarding the milk composition, protein (\%) was higher $(\mathrm{p}<0.05)$ with feeding on Exp.1 than feeding on Exp.2 or Exp.3 (2.42, 2.26 and 2.28) respectively, but there was no significant effect with the control ration (2.37) and there was no significant effect between the control and Exp.3. Milk total solids (\%), fat $(\%)$, lactose $(\%)$, solids non-fat $(\%)$, net energy of lactation (Mcal $/ \mathrm{Kg}$ ), fat corrected milk ( $\mathrm{Kg} /$ day), fat yield (Kg / day), protein yield (Kg / day) and lactose yield (Kg / day) did not significantly affect by dietary treatments. The best values of feed conversion (dry matter intake $\mathrm{Kg} / \mathrm{Kg}$ fat corrected milk) were with feeding on rations containing corn gluten feed: Exp.1, Exp.2 and Exp.3 (1.15, 1.14 and 1.16) respectively, than the control (1.27) which was without corn gluten feed. The highest values of the profit (LE) were with feeding on Exp.1, Exp.2 and Exp.3 (29.08, 30.64 and 30.32) than feeding on the control one (23.72), respectively. The replacement of amounts of corn grain and cottonseed meal in the concentrate feed mixture in lactating cows rations by $15 \%$ corn gluten feed are often considered for enhancing production of milk, persistency and economic efficiency.

Keywords: lactating Friesian cows, Corn silage, Corn gluten feed, Milk production and Milk composition

\section{INTRODUCTION}

There is a deficiency in animal feeds (27\% of calculated requirements) in the northern countries of Africa (Egypt, Algeria, Libya, Morocco and Tunisia). Over the whole year, Usage of the available feed quantities is not at a constant rate. During the winter (rainfall) season, the more nutritious $65 \%$ of available feeds are consumed. While in summer season, animals suffer from severe feed insufficiency due to lack of minerals, nitrogen, vitamin A precursors and soluble carbohydrates at the same time. The northern countries of Africa have considerable amounts of crop residues and agro-industrial by-products which are under utilized. Also, in milk production a diet based on chopped and supplemented by-products resulted in a similar level of milk yield as that obtained on a 1:1 concentrate to green roughage diet (on DM basis), (Kossila,1981).

Removal of starch content of new material is done in most cases. After concentrating the remaining material, the raw product from which they originate is lower in protein, fiber and fat. Despite removing the rapidly-digested starch from the feed, fiber in the form of cellulose remains and is highly digestible by ruminants such as cattle and sheep. Consequently, the energy (TDN) content of these feeds is not very different from the TDN of the whole grain from which these by-products originate (Wahlberg, 2009).

Corn by-products continue to be economical sources of nutrients. Maintaining energy levels and decreasing feed costs can be achieved by using wheat midds, corn gluten feed and soy hulls. Dairy managers and nutritionists must monitor corn by-products as ethanol producers continue to market corn nutrients in by products (Hutjens, 2010), to capture value - added feed markets.

Feed related values are monitored, including feed cost per pound of dry matter (DM), feed cost per cwt (100 $\mathrm{lb}$ of milk), feed efficiency and income over feed cost, permit dairy managers to assess their feeding programs, (Hutjens 2011). Higher forage based rations and strategic use of by- product feeds will be considered.

Simply, acetic acid is produced by fermentation of fiber (cellulose and hemicellulose), then acetic acid is used for energy by the cow and as a primary precursor of fat in milk. In contrast, propionic acid is produced from digestion of sugars and starches, then in the liver of the cow propionic acid is changed into glucose and used for energy (Grant, 1997). Corn gluten feed is a by-product of corn syrup manufacturing. This feed has protein that is mostly degradable in the rumen and is not considered a source of rumen resistant protein, while energy is similar to some grains. Corn gluten feed is often an economical feed to use in rations.

The objective of this study was to evaluate the effect of partially substituting of corn and undecorticated cottonseed meal by corn gluten feed on production of milk, feed utilization and economic efficiency of lactating Friesian cows.

\section{MATERIALS AND METHODS}

The present study was conducted at El-Karada Animal Production Research Station, Animal Production Research Institute, Agricultural Research Centre, Ministry of Agriculture. In this study, the weight of the twelve cows 
was ranging from $435-570 \mathrm{~kg}$. The animals in this study were in the 2 nd to 4 th lactation season. In order to study the production of milk and its composition by the effect of the feeding tested rations, cows were subdivided into four groups (three cows in each group). According to NRC (2001) recommendations all groups were fed individually. The period of the experiment was 140 days (20 weeks) after 6 weeks from calving. The four experimental rations were formulated nearly as follows: control: $52 \%$ concentrate feed mixture (CFM) (40\% corn grain, 30\% wheat bran, $23 \%$ undecorticated cottonseed meal, $5 \%$ molasses, $0.5 \%$ salt and $1.5 \%$ limestone) $+20 \%$ corn silage $(\mathrm{CS})+28 \%$ rice straw $(\mathrm{RS})$, experimental ration 1 (Exp.1): 52\% CFM (35\% corn grain, 30\% wheat bran, $10 \%$ corn gluten feed (CG), 18\% undecorticated cottonseed meal, 5\% molasses, $0.5 \%$ salt and $1.5 \%$ limestone) $+20 \% \mathrm{CS}+28 \% \mathrm{RS}$, (Exp.2): 52\% CFM $32.5 \%$ corn grain, $30 \%$ wheat bran, $15 \%$ CG, $15.5 \%$ undecorticated cottonseed meal, $5 \%$ molass, $0.5 \%$ salt and $1.5 \%$ limestone) $+20 \% \mathrm{CS}+28 \% \mathrm{RS}$ and (Exp.3): $52 \%$ CFM (30\% corn grain, 30\% wheat bran, 20\% CG, $13 \%$ undecorticated cottonseed meal, $5 \%$ molasses, $0.5 \%$ salt and $1.5 \%$ limestone) $+20 \% \mathrm{CS}+28 \% \mathrm{RS}$.

Firstly at morning, concentrate feed mixture was given individually. Then after consuming the concentrate feed mixture, corn silage and rice straw were given. The drinking water was clean, fresh and available at all times.

Recording the yield of milk was done twice daily individually for each cow. Proportionating sample from morning and evening was done during periods of the experiments. During these periods, all the experimental rations in the end of 4 weeks, about $0.5 \%$ of the total milk yield was taken for analysis from each animal individually. The analysis included fat, total protein, lactose, total solids (TS) and solids non-fat (SNF) in milk. According to Ling (1963), the chemical analysis of milk samples was done. At the beginning, middle and at the end of each trial, samples of concentrate mixture, corn gluten fed, corn silage and rice straw were taken.

In a forced air oven for $48 \mathrm{hrs}$ (with a temperature of $65^{\circ} \mathrm{C}$ ), corn silage samples were dried at the end of the trials then all samples were dried at $105^{\circ} \mathrm{c}$ for 3 hours, and ground and preserved for chemical analysis.

For each cow, composting dried samples was done and taking representative samples was carried out to be preserved for chemical analysis.

According to the methods of AOAC (1990), For determination of dry matter (DM), crude protein (CP), crude fiber $(\mathrm{CF})$, ether extract (EE), ash and fiber fractions (NDF,ADF ADL, hemi. and cell), chemical analysis of concentrate mixture samples, corn gluten fed, corn silage and rice straw were done.

According to Snedecor and Cochran (1982), data were analysed statistically by variance test method while Duncan's Multiple Test was used for testing the differences between means. (Duncan, 1955)

\section{RESULTS AND DISCUSSION}

Chemical composition of the ingredients and experimental rations were as shown in table (1). The CP\% was higher for CG 10\%, CG 15\% and CG20\% and lower in $\mathrm{CF}, \mathrm{ADF}$ and $\mathrm{ADL} \%$. However, the concentrate feed mixtures with or without $\mathrm{CG}$ were contained similar values of NFE, Ash, NDF, hemicellulose and NFC \%. The chemical composition of the experimental rations were contained similar of all nutrients. The $\mathrm{CP} \%$ values ranged from 10.32 to $11.85, \mathrm{ADF} \%$ values were from 34.56 to 35.41 and NFC\% values were ranged from 25.94 to 26.35 .

The average daily dry matter intake of each experimental ration was shown in Table (2). The dry matter intakes (\% body weight) were higher with feeding on Exp.1 or Exp.2 (3.38 and 3.51, respectively) than feeding on control or Exp.3 (3.25 and 3.26) respectively. The NRC (1989) recommends that diets for lactations dairy cows should contain minimum of $25 \%$ to $28 \%$ of the total DM as NDF, and it is suggested that $75 \%$ of that NDF should be from a forage source. For providing highly digestible neutral detergent fiber (NDF) and non-fiber carbohydrates, utilization of more by-product feeds and high-quality forage was suggested as a strategy for lactating cow diets with high corn prices (Shaver, 2008).

Table 1.The chemical composition of the ingredients and rations of the experiment.

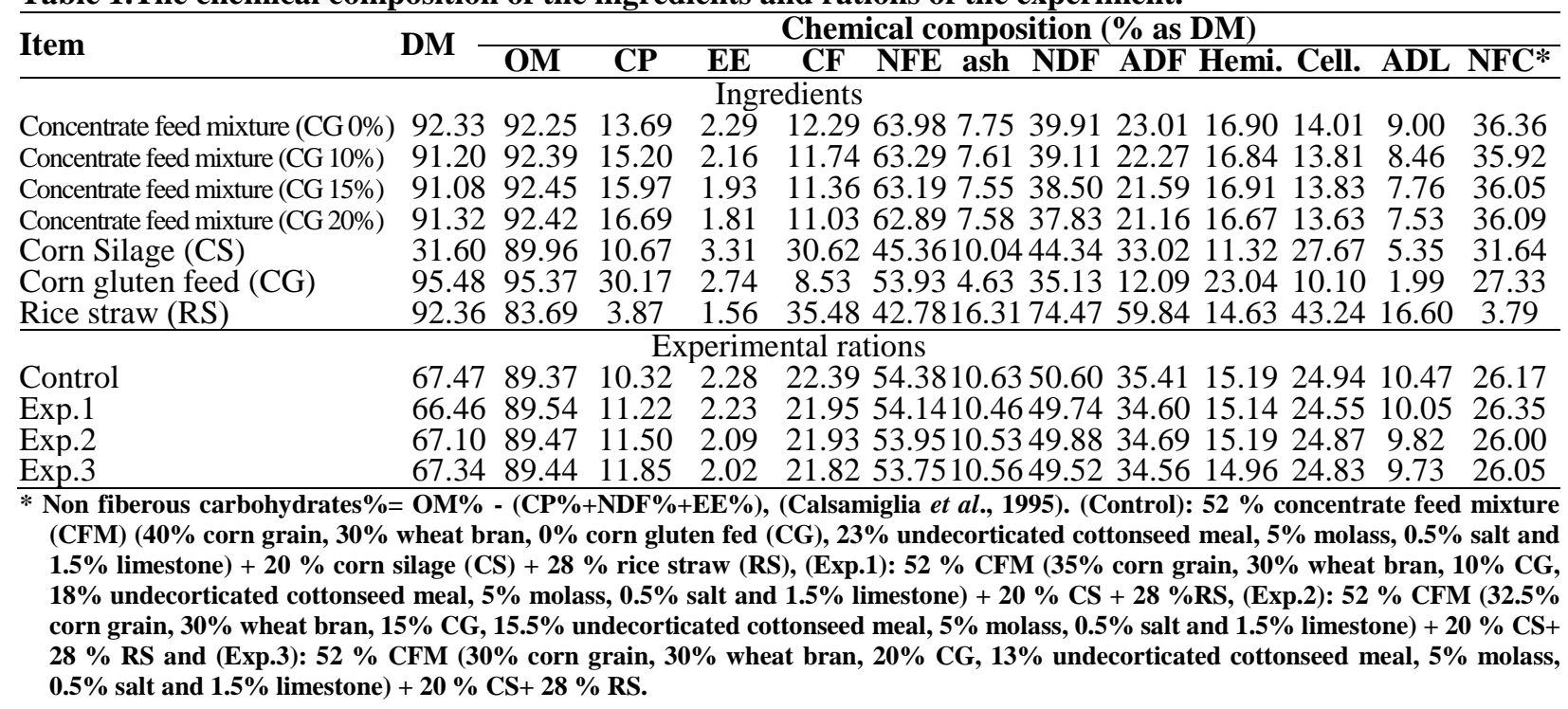


Table 2. Average daily dry matter intake of concentrate feed mixture, corn silage and rice straw by dairy cows.

\begin{tabular}{|c|c|c|c|c|}
\hline Items & Control & Exp.1 & Exp.2 & Exp.3 \\
\hline Average body weight (kg) & 535 & 485.7 & 491.7 & 510 \\
\hline \multirow{2}{*}{ Concentrate : roughage } & $52.42:$ & $52.84:$ & $52.26:$ & 52.26 : \\
\hline & 47.58 & 47.16 & 47.74 & 47.74 \\
\hline \multicolumn{5}{|c|}{ Intake of (DM): Concentrate feed mixture (CFM) : } \\
\hline $\mathrm{Kg} / \mathrm{h} / \mathrm{d}$ & 9.08 & 8.66 & 9.03 & 8.68 \\
\hline$\% \mathrm{BW}$ & 1.70 & 1.79 & 1.84 & 1.71 \\
\hline \multicolumn{5}{|c|}{ Intake of (DM): Corn silage $(\mathrm{S})$ : } \\
\hline $\mathrm{Kg} / \mathrm{h} / \mathrm{d}$ & 3.32 & 3.27 & 3.32 & 3.16 \\
\hline$\% \mathrm{BW}$ & 0.62 & 0.68 & 0.67 & 0.62 \\
\hline \multicolumn{5}{|c|}{ Intake of (DM): Rice straw (RS): } \\
\hline $\mathrm{Kg} / \mathrm{h} / \mathrm{d}$ & 4.93 & 4.46 & 4.93 & 4.77 \\
\hline$\% \mathrm{BW}$ & 0.92 & 0.92 & 1.00 & 0.94 \\
\hline \multicolumn{5}{|c|}{ Total dry matter intake: } \\
\hline $\mathrm{Kg} / \mathrm{h} / \mathrm{d}$ & 17.32 & 16.39 & 17.28 & 16.61 \\
\hline$\% \mathrm{BW}$ & 3.25 & 3.38 & 3.51 & 3.26 \\
\hline \multicolumn{5}{|c|}{ TDN intake: } \\
\hline TDN\% & 72.74 & 70.18 & 66.45 & 68.80 \\
\hline TDN intake $(\mathrm{Kg})^{*}$ & 12.60 & 11.50 & 11.48 & 11.43 \\
\hline \multicolumn{5}{|c|}{ DCP intake: } \\
\hline $\mathrm{DC} \mathrm{DCP} \%$ & 7.70 & 7.62 & 7.14 & 7.65 \\
\hline DCP intake $(\mathrm{Kg})^{* *}$ & 1.33 & 1.25 & 1.23 & 1.27 \\
\hline
\end{tabular}

These strategies can lead to a lower dietary content of starch. There will be a low protein content in corn and corn silage, relative to the cattle's needs. Providing sufficient protein is a necessity. Stallings (2000) suggested that the feed maximums were 0.8 and $0.5 \%$ of $\mathrm{BW}$ for corn gluten feed and whole cottonseed meal, respectively. It becomes unclear as to what the maximums should be, when combinations of these feeds are utilized. Generally, limit combinations of these feeds to no more than $25 \%$ of the ration dry matter.

In tables (3 and 4), Average daily milk yield and its chemical composition are presented respectively. The average daily milk yield with feeding the experimental rations was not significantly affected from Week 1 to Week 20. The average milk yield results were 13.68, 14.71, 15.73 and $14.79 \mathrm{Kg} /$ day with feeding on the control, Exp.1, Exp.2 and Exp.3, respectively. The highest value was with feeding on Exp. 2 than the other rations.

Table 3. The experimental rations effect on average daily milk yield $(\mathrm{kg} / \mathrm{d})$ of the lactating Friesian cows from 1 up to 20 weeks.

\begin{tabular}{lccccc}
\hline Items & Control & Exp.1 & Exp.2 & Exp.3 & SEM \\
\hline W1-4 & 16.48 & 14.56 & 15.44 & 15.56 & 1.256 \\
W5-8 & 13.46 & 16.36 & 16.10 & 15.60 & 1.215 \\
W9-12 & 13.55 & 15.98 & 16.16 & 15.22 & 1.050 \\
W13-16 & 12.18 & 14.11 & 15.91 & 14.40 & 1.253 \\
W17-20 & 12.72 & 12.52 & 15.03 & 13.18 & 1.267 \\
$\begin{array}{l}\text { Average } \\
\text { daily milk }\end{array}$ & 13.68 & 14.71 & 15.73 & 14.79 & 1.099 \\
\hline
\end{tabular}

For lactating dairy cows, corn gluten feed is involved in rations as a source of energy, fiber and protein. It has a similar energy value to that of corn, and contains three times as much crude protein. When used as a substitution of corn, it decreases the nonstructural carbohydrate (NSC) level of the diet effectively with minimal effects upon the content of energy. Generally, it is an efficient replacement for concentrate alone or forage and concentrate without significant effects upon DM intake or fat corrected milk production, Fellner and Belyea (1991).

Table 4. Impact on some chemical composition of milk by feeding lactating cows on experimental rations

\begin{tabular}{|c|c|c|c|c|c|}
\hline Items & Contro & Exp.1 & Exp.2 & Exp.3 & SEM \\
\hline$\overline{\mathrm{T} . \mathrm{S} \%}$ & 11.04 & 11.03 & 10.11 & 10.27 & 0.441 \\
\hline Fat $\%$ & 3.56 & 3.41 & 3.29 & 3.44 & 0.210 \\
\hline Lactose $\%$ & 4.57 & 4.80 & 4.64 & 4.45 & 0.147 \\
\hline Protein $\%$ & $2.37^{\mathrm{ab}}$ & $2.42^{\mathrm{a}}$ & $2.26^{\mathrm{c}}$ & $2.28^{\mathrm{bc}}$ & 0.029 \\
\hline SNF\% & 7.48 & 7.62 & 6.82 & 6.83 & 0.323 \\
\hline $\mathrm{NE}_{\mathrm{L}}(\mathrm{Mcal} / \mathrm{Kg})^{*}$ & 0.64 & 0.64 & 0.61 & 0.62 & 0.022 \\
\hline Fat corrected milk (FCM) & 13.78 & 14.51 & 15.17 & 14.71 & 1.464 \\
\hline Fat yield (Kg/day) & 0.485 & 0.503 & 0.516 & 0.513 & 0.062 \\
\hline Protein yield ( $\mathrm{Kg} /$ day) & 0.348 & 0.357 & 0.354 & 0.337 & 0.027 \\
\hline Lactose yield (Kg/day) & 0.667 & 0.708 & 0.728 & 0.660 & 0.052 \\
\hline
\end{tabular}

a, $b$ and c: Means within the same row with different superscripts are significantly different $(\mathbf{p}<0.05)$.

$* \mathrm{NE}_{\mathrm{L}}(\mathrm{Mcal} / \mathrm{kg})=(\mathbf{0 . 0 9 2 9} \times$ Fat \% $)+(0.0547 \times$ Protein \% $)+$ $(0.0395 \times$ Lactose \%) (NRC, 2001).

**FCM: Average of dairy production of calculated $3.5 \%$ fat corrected milk (Kg/day).

FCM $(\mathrm{Kg} /$ day $)=0.432 \times$ milk $(\mathrm{Kg})+16.23 \times$ fat $(\mathrm{Kg})($ Britt and Broderick, 2003).

Concerning the composition of milk, protein $\%$ was higher $(\mathrm{p}<0.05)$ with feeding on Exp.1 than feeding on Exp.2 or Exp.3 (2.42, 2.26 and 2.28) respectively, but there was no significant effect with the control ration (2.37) and there was no significant effect between the control and Exp.3. Milk TS \%, fat \%, lactose $\%$, SNF \%, NEL (Mcal /Kg), FCM Kg / day, fat yield, protein yield and lactose yield $\mathrm{Kg} /$ day did not significantly affect by dietary treatments.

As shown in fig. (1) that the average milk yield was higher first week of experiment with feeding on the control diet $(17.62 \mathrm{~kg} / \mathrm{d})$ then feeding on Exp.1 or Exp.2 or Exp.3 (14.07, 16.47 and $15.41 \mathrm{~kg} / \mathrm{d})$ respectively, then milk yield tended to decrease until week 20 with feeding on control diet with total average $(13.68 \mathrm{~kg} / \mathrm{d})$, while milk yield increased with feeding on Exp.1, Exp.2 and Exp. 3 up to 20 week, but milk yield tended to be more with feeding on Exp.2 in week 12 up to week 20 than feeding on Exp.1 or Exp.3.

The total average of milk yield with feeding on Exp.1, Exp.2 and Exp.3 were 14.71, 15.73 and 14.7 $\mathrm{kg} / \mathrm{d}$ respectively.

As shown in fig. (2), the same trend was noticed with the average milk fat yield. The total average milk fat yield with feeding on control, Exp.1, Exp.2 and Exp.3 were $0.485,0.503,0.516$ and $0.513 \mathrm{~kg} / \mathrm{d}$, respectively. 


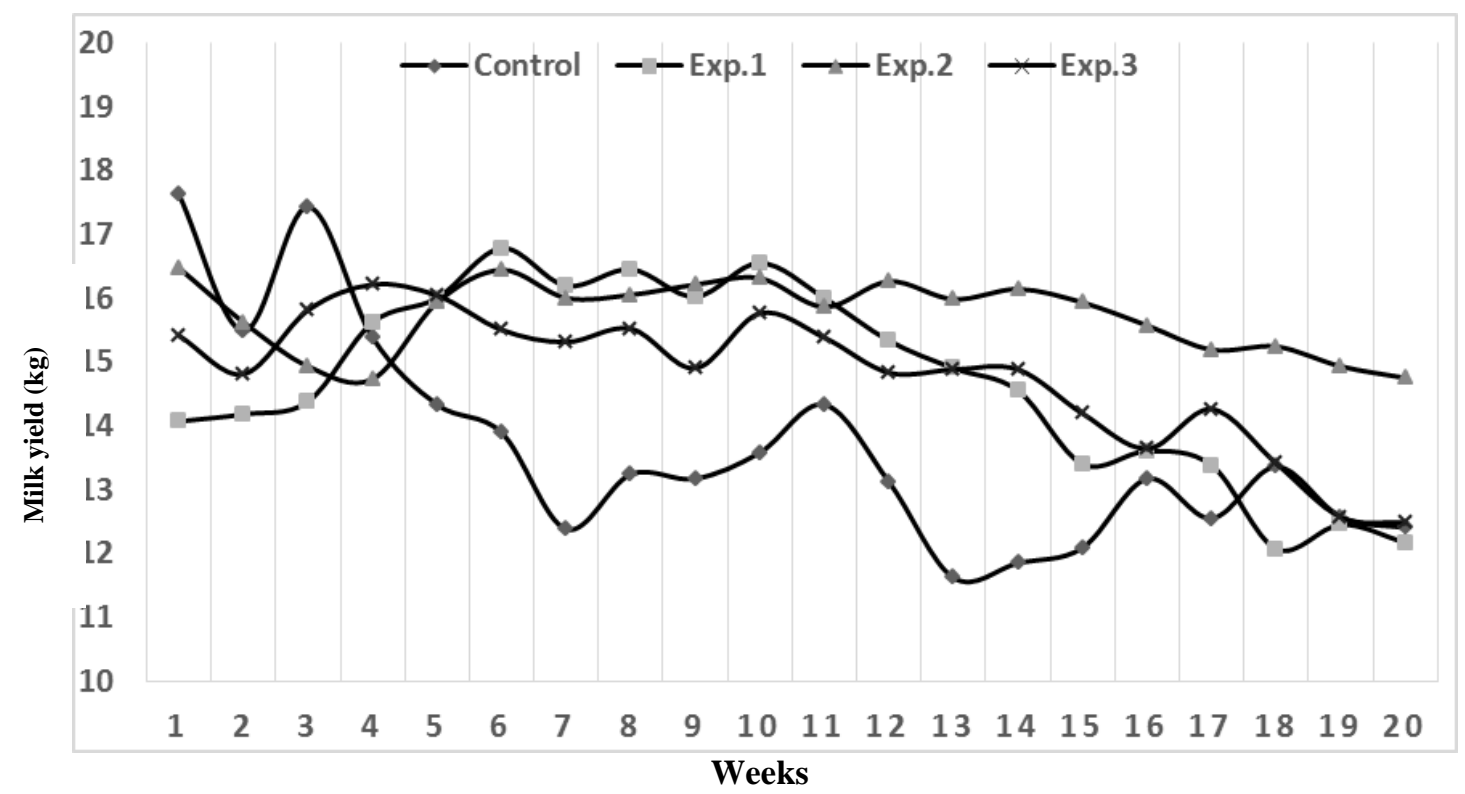

Fig. 1. The experimental rations effect on average daily milk yield $(\mathrm{kg} / \mathrm{d})$ from 1 up to 20 weeks.

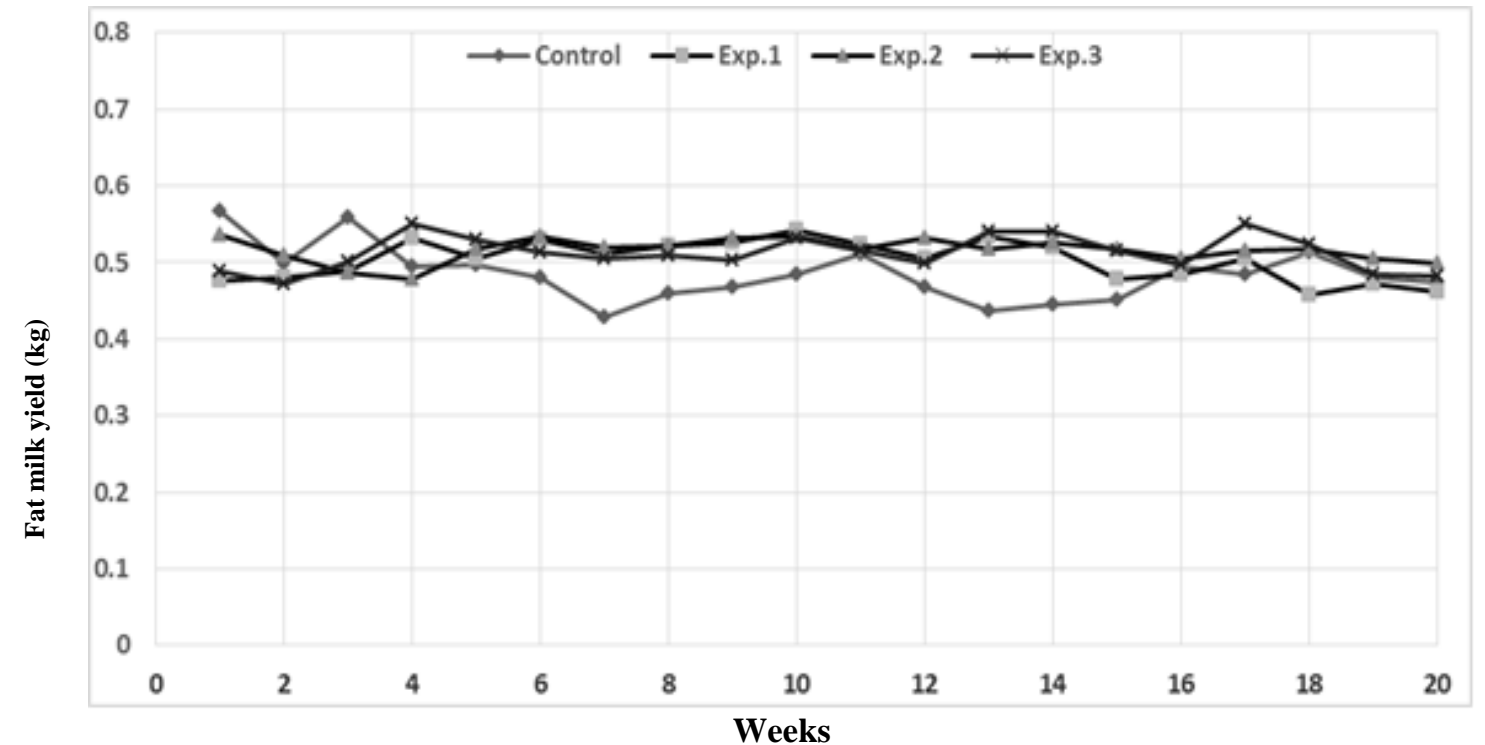

Fig. 2. The experimental rations effect on average daily fat milk yield ( $\mathrm{kg} / \mathrm{d})$ from 1 up to 20 weeks.

Lactation curve shape analysis is beneficial in recognizing feeding and management problems within a dairy herd. High peak and persistency are required for high production. During the entire lactation period, 200$230 \mathrm{~kg}$ extra milk should be predicted for every extra $\mathrm{kg}$ of milk at peak lactation (Wachirapakorn, 2004).

The correlation between feeding practice and milk yield and composition was found that dry matter intake was highly correlated to milk yield, $(r=0.73$, $\mathrm{P}<0.01)$, but negatively correlated to milk protein $(\mathrm{r}=$ $0.26, \mathrm{P}<0.01)$.

While, the high roughage ration was negatively correlated to milk yield $(\mathrm{r}=-0.65, \mathrm{P}<0.01)$, and milk lactose $(\mathrm{r}=-0.54, \mathrm{P}<0.01)$. On the other hand, it was positively correlation to milk fat $(\mathrm{r}=0.34, \mathrm{P}<0.01)$ and milk protein $(\mathrm{r}=0.28, \mathrm{P}<0.05)$. Crude protein of diet did not affect milk composition while there is a reduction in milk protein and also total solid by high rumen degradable protein (RDP) in diet.

Several by-products, however, have two or more of these properties. For example, corn gluten feed have high content of protein plus a high readily fermentable carbohydrates level.. In the ration, degradable ruminal protein should be about $65 \%$ of the total crude protein. The degradable ruminal protein of the feed at less than $60 \%$ of the total protein, will decrease milk yield and component productions. Starch and sugars, expressed as non-fiber carbohydrates, have an effect on milk yield, protein and fat percentage. There is an increase in the percentage of protein and possibly yield by excess NFC, but there is a reduction in fat percentage. Corn syrup manufacturing produces corn gluten feed. This feed contains protein that is mostly degradable in the rumen and is not considered a source of rumen resistant protein. Energy is similar to some grains. Corn gluten feed has an economical value to be used in rations.

The data in table (5) showed that the feed conversion best values (DMI $\mathrm{Kg} / \mathrm{Kg} \mathrm{FCM}$ ) were with feeding on rations containing corn gluten feed: Exp.1, Exp.2 and Exp.3 (1.15, 1.14 and 1.16) respectively, compared with the control (1.27) which was without corn gluten feed. 
Table 5. Impact on feed conversion and economic efficiency by feeding the experimental rations to the lactating cows.

\begin{tabular}{lccccc}
\hline Items & Control & Exp.1 & Exp.2 & Exp.3 & SEM \\
\hline & Average daily & feed consumption (as fed): & & & \\
Concentrate feed mixture Kg & 9.83 & 9.50 & 9.92 & 9.50 & 0.557 \\
Silage (S) Kg & 10.50 & 10.33 & 10.50 & 10.0 & 0.565 \\
Rice straw (RS) Kg & 5.33 & 4.83 & 5.33 & 5.17 & 0.300 \\
\hline & \multicolumn{2}{c}{ Average daily production: } & & \\
DMI (Kg/h/day) & 17.32 & 16.40 & 17.28 & 16.61 & 0.830 \\
Fat corrected milk (FCM Kg/day) & 13.78 & 14.51 & 15.17 & 14.71 & 1.464 \\
DMI Kg/ Kg FCM & 1.27 & 1.15 & 1.14 & 1.16 & 0.096 \\
Price of FCM (LE)/day & 70.27 & 73.99 & 77.36 & 75.01 & 7.466 \\
Cost of total feeds (LE)/ day & 46.55 & 44.91 & 46.72 & 44.69 & 2.445 \\
Profit (LE) as total feed/day & 23.72 & 29.08 & 30.64 & 30.32 & 5.672 \\
\hline
\end{tabular}

* FCM: Average of dairy production of calculated $3.5 \%$ fat corrected milk (Kg/day).

FCM $(\mathrm{Kg} /$ day $)=0.432 \times$ milk $(\mathrm{Kg})+\mathbf{1 6 . 2 3} \times$ fat $(\mathrm{Kg}),($ Britt and Broderick, 2003)

Market price $\mathrm{LE} / \mathrm{kg}$ of: $\mathrm{FCM}=5.10 \mathrm{LE}$, concentrate feed mixture $=3.813 \mathrm{LE}$, concentrate feed mixture $(10 \%$ corn gluten feed $)=3.803$ LE, concentrate feed mixture $(15 \%$ corn gluten feed $)=3.798 \mathrm{LE}$, concentrate feed mixture $(20 \%$ corn gluten feed $)=3.793 \mathrm{LE}$, cottonseed meal $=5.1 \mathrm{LE}$, corn grain $=3.5 \mathrm{LE}$, corn gluten feed $=4.2 \mathrm{LE}$, fresh silage $=0.7 \mathrm{LE}$, and rice straw $=0.33 \mathrm{LE}$.

It is known that the production of milk depends highly on the amount of energy a cow consumes (Staples, 2003). In addition to energy, lactation cow needs fiber for normal rumen performance. The high energy forage requirement is therefore obvious.

This would be helpful in dairy production, since dairy cows have to keep a balance between taking in a high level of energy and maintaining normal ruminal fermentation (Kajikawa et al, 1993). Thus, the reason why dairy farmers often use by-product feeds is due to considering these feeds to be a way, not only of lowering costs, but of increasing production.

Also, table (5) showed that the highest values of the profit (LE) were with feeding on Exp.1, Exp.2 and Exp.3 (29.08, 30.64 and 30.32) respectively, than feeding on the control (23.72). Corn by-products has a great economical value as a source of nutrients. Corn gluten feed is capable of preserving energy levels while lowering costs of feed. As ethanol producers continue to market corn nutrients in by products, monitoring corn by-products must be done by dairy managers and nutritionists (Hutjens, 2010).

Economic considerations and forage inventories sometimes result in using commodities containing large amounts of soluble fiber and rapidly digestible NDF to replace forage fiber. There is a high amount of rapidly digestible NDF in these feeds but marginal levels of effective fiber (Hinder, 2000).

In lactating cows rations, It is deduced that the substitution of amounts of corn grain and cottonseed meal in the concentrate feed mixture by $15 \%$ corn gluten feed are often considered for enhancing production of milk, economic efficiency, while substitution of corn and cottonseed meal at a level of at least $10 \%$ (DM basis) improve utilization fed nitrogen, such substitution resulted in improving percentage of milk protein.

\section{REFERENCES}

AOAC (1990). Association of Official Analytical Chemists. Official Methods of Analysis. 15th Ed., Washington DC.
Britt, A.F. and Broderick, G.A. (2003). Effects of different dietary rations of alfalfa and corn silage on milk production and rumen metabolism in lactating dairy cows. J. Dairy Sci. 86 (Suppl. 1): 62 (Abstract).

Calsamiglia, S.; M.D. Stern and J.L. Firkins (1995). Effects of protein source on nitrogen metabolism in continuous culture and intestinal digestion in vitro. J. Anim. Sci., 73: 1819.

Duncan, D.B. (1955). Multiple Range and Multiple F Test. Biometrics, 11:10.

Fellner, V. and Belyea, R.L. (1991). Maximizing gluten feed in corn silage diets for dairy cows. J. Dairy Sci. 74:996.

Grant, R.J. (1997). Interactions among forages and nonforage fiber sources. J. Dairy Sci.80:1438

Hinder, R. (2000).Common by-product feedstuffs nutrient profiles confirmed in California study. Feedstuffs, September 11, 2000, P. 10.

Hutjens, M.F. (2010). Feeding economic for 2010. Proc. four state dairy nutrition and management conference. pp 27.

Hutjens, M.F. (2011). Changes in feeding dairy cows during the last 20 years and what's ahead. Tristate dairy nutrition conference, University of Illinois.

Kossila, V.L. (1981). Reviews on the potential for be utilization of crop residues and agro-industrial by-products in developing countries. FAO, Rome, Italy.

Ling, E.R. (1963). A Text Book of Dairy Chemistry. $2^{\text {nd }}$ Ed. Academic Press, New York and London, 1.

National Research Council (1989). Nutrient requirements of dairy cattle. 6th Ed. Natl. Acad. Sci. Washington, DC.

National Research Council (2001). Nutrient requirements of dairy cattle. 7th rev. ed. National Academy Press, Washington, DC

Shaver, R.D. (2008). Coping with high corn prices: low starch diets and lactation performance by dairy cows. Pages 128-133 in proc. 6th Mid-Atlantic Nutr. Conf. Timonium, MD. 
Snedecor, G.W. and Cochran, W.G. (1982). Statistical Methods. 7th Ed. Iowa State Univ. Press. Ames. Iowa.

Stallings, C.C. (2000). Limit these feeds in rations for dairy cattle. Dairy science, Virginia cooperative extension, Virginia state university. Staples, C.R. (2003). Corn silage for dairy cows. Florida cooperative extension service, Institute of food agricultural sciences, university of Florida.
Wachirapakorn, C. (2004) Feeding strategies and milk composition in dairy cows. Department of animal science. Faculty of Agriculture Khon Kaen University, Kon Kaen 40002, Thailand.

Wahlberg, M.L. (2009). Alternative feeds for beef cattle. Virginia polytechnic institute and state university.

\section{تأثثر التفذية على مستويات مختلفة من الجلوتوفيد على إنتاج اللبن والكفاءة الإقتصادية في علائق الأبقار الفريزيان الحلابة.

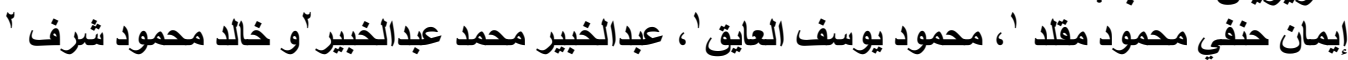

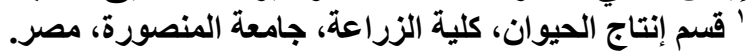

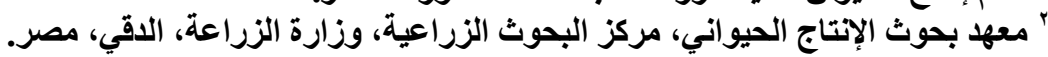

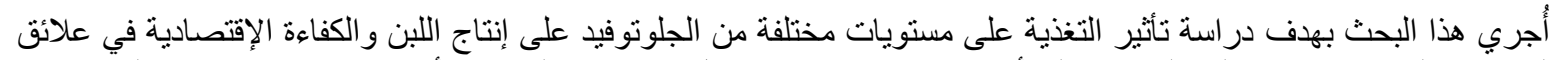

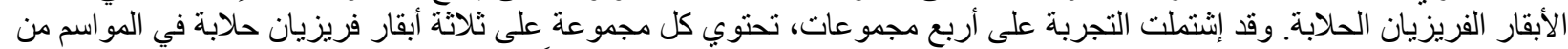

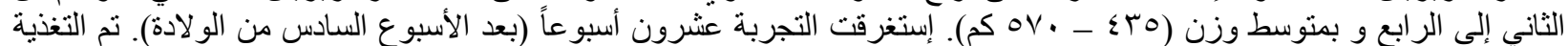

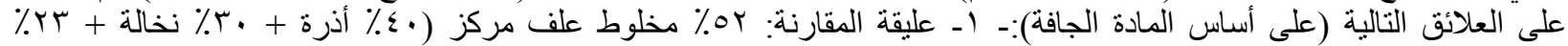

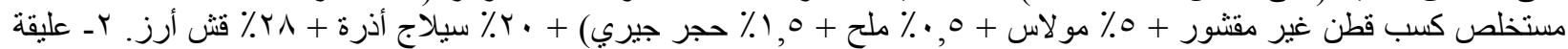

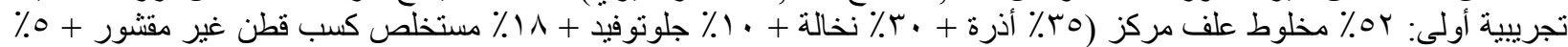

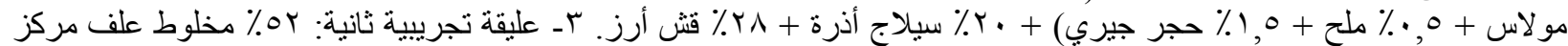

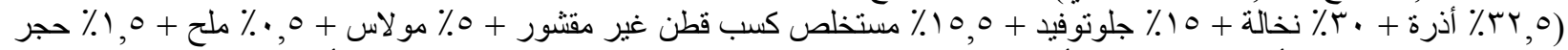

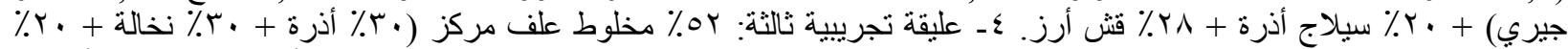

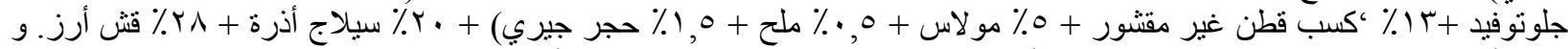

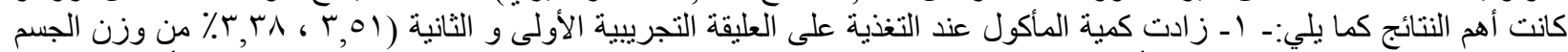

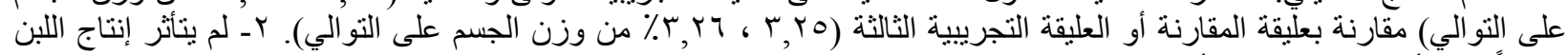

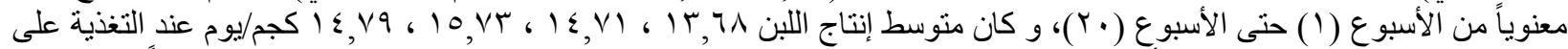

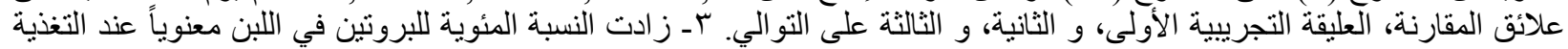

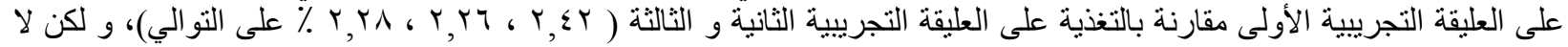

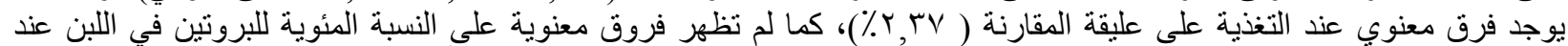

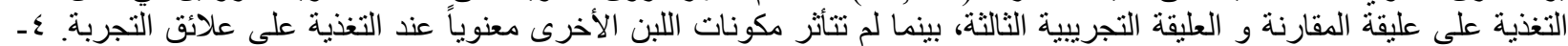

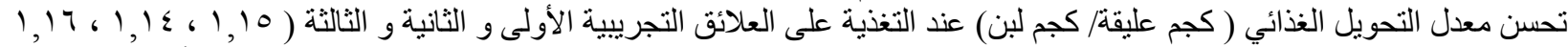

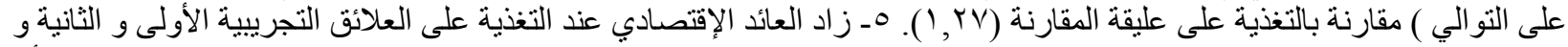

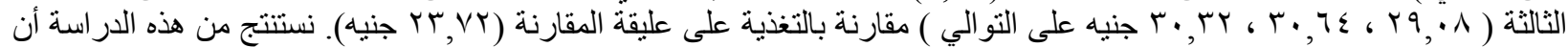

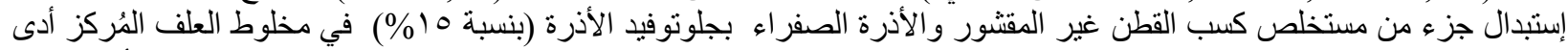

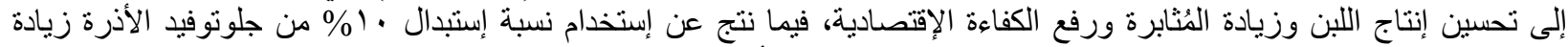

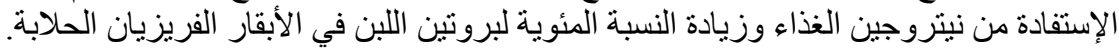

